\title{
Practice Teaching Base Construction in Universities -Taking City Management Major as an Example
}

\author{
C.S. LIU, B. SHI, L.L. LIU, X.L. ZHOU \\ Beijing City University, Beijing, China
}

\begin{abstract}
Based on the analysis of the meaning and basic characteristics of the practical teaching base, the paper introduced the basic foundation of city management professional practice teaching base construction, mainly from three aspects of the professional orientation and practice base construction, teaching reform and practice base construction, the method and practice base construction. Finally the author put forward the thinking of urban management practice teaching base construction in city management major, focus on six aspects of the mutual reciprocity and mutual benefit and win-win cooperation, the values of people-oriented, open and diversified mechanism, resource sharing and social education, consistent with the major teaching organization, to grasp complementary relationship of the practice base construction on campus and off campus, and provided reference and reference for the practice teaching base construction of colleges and universities.
\end{abstract}

KEYWORD: Practice teaching; Base construction; City management; Construction thoughts

With deepening of socialist market economic system in China, industrial structure upgrade, constantly deepening development of urbanization process, the importance of city management, construction and management problems emerged, and the construction of urban development and displayed in the construction of the overall development of our country of the increasingly prominent role also accelerated the rapid development of urban management. The popularization of higher education also result in colleges and universities are no longer is the cradle of elite talent, and social demand for student academic level gradually improved, and put forward new requirements for operational ability of students to enter the workplace. Therefore, the undergraduate education in colleges and universities of positioning needs to be reviewed. This shows that colleges and universities in the undergraduate stage gradually change education teaching methods, the introduction of practical teaching mechanism, and it is necessary to carry out the practice teaching base construction.

\section{THE MEANING AND CHARACTERISTICS OF PRACTICE TEACHING BASE}

\subsection{The meaning of practice teaching base}

College practice base is refers to the colleges and universities in accordance with the requirements of the higher education goals for college students to plan, organized, with the purpose of going deep into the actual society, participating in specific production and social life, increasing knowledge and understanding of society, and it is the stability of the carrier for training quality and students' teaching practice and improving quality and ability education. It is almost fixed over a period of time, has special social practice content, clear development plan and a relatively stable team of implementation.

\subsection{The characteristics of practice teaching base}

\subsubsection{Goal-oriented}

Construction is carried out in accordance with the requirements of the training goal of colleges and universities. Generate the all-round development of morality, intelligence and physique of builders and successors of the socialist is the training objective of higher education in the new period. As a collaborator of college education practice base, should serve for training builders and reliable successors of socialism.

\subsubsection{Relatively stable}

Practice base is the system composed by a series of bases, is an indispensable entity for college students quality education. This requires that the stability of 
the base and the system stability. School and practice base should establish long-term, stable relations of cooperation, not because of some personnel changes lead to relationship change. Only in this way, students' practice ability has a relatively stable environment.

\subsubsection{Major-related}

All kinds of professional practice base is closely associated with college education of majors, is the combination of theory and practice. Teaching practice base can be compatible with the teaching target, teaching characteristics of colleges and universities, training objective, course construction, can meet the requirements of relevant professional talent training, can provide for the teaching practice with the corresponding equipment, location, etc.

\subsubsection{Functional complementation}

The main functions of the different practice base are different. Therefore, as far as possible to establish various types of bases, in order to realize the complementary functions and playing a different role. Some practice bases can reflect the basic features of the country, society, and the time, is the one side of the window for college student to understand the social and times. Some practice base can make college students constantly comparison with the school professional knowledge and social need with the practical knowledge, and constantly to shape themselves into talents that are compatible with national and social development. Some practice base can provide adequate social resources for entrepreneurship of university students' employment, is an ideal place for business in employment. Only combining with different bases, practice base can give full play to the teaching practice of college students' education.

\section{THE BASIC FOUNDATION OF CITY MANAGEMENT PROFESIONAL PRACTICE BASE CONSTRUCTION}

\subsection{Major orientation and practice base construction}

The major is the basic education units of colleges and universities cultivate advanced talents, is consist of a specific professional training objectives and corresponding curriculum system. Orientation of major training goal is different, the requirement of theory teaching and practice teaching are also different, and thus the contents and modes of the construction of practice base also have difference. Therefore, colleges and universities undergraduate specialty orientation, the choice of direction have important influence on practice base construction, and become the important basis of the construction of practice base.
City management professional positioning can not only for a single specific job but for a variety of professions and jobs, and cultivating students should satisfy the needs of the production, technology, society and the urban development. Based on this understanding, the design of the urban management professional practice base and positioning should be to adapt to the career or job group as the goal. Urban and social management demand variability and undergraduate orientation need to be relatively stable. City management professional position, therefore, need to make combination of stability and variability, improve the personnel training of relative stability and flexibility. The positioning of city management should cater to the market, confirm professional positioning in colleges and universities based on its own hardware and software conditions, mainly aimed at the needs of society. In city management professional orientation, the practice teaching base should also make full use of geographical advantages, focus on running well majors those have good prospects for development, and can satisfy the city in the region and the professional direction of social management development needs, and through a period of time accumulated, gradually formed their own professional advantages and characteristics.

\subsection{The curriculum reform and the practice base construction}

A professional division of cooperation between various courses constitutes the curriculum system, and curriculum system is mainly reflected by the ratio between various kinds of curriculum, and reasonableness of the course system is directly related to the quality of the training. Obviously, a professional curriculum system affects the basic form of the practice base, decides practice basic content. In the course of the implementation of the process, three aspects must be grasped: the content of the course of theoretical depth, the integration of theory with practice, and the matching degree of curriculum and work.

Theoretical depth of courses refers to the content. According to the requirements of the city management professional training objectives, the students should own deeper theoretical basis, skills are mainly refer to innovative skills.

The integration of theory and practice is refers to the degree of mutual fusion and mutual support, mutual promotion the course between theory and practice. The integration of theory and practice is better, the teaching effect is also better. Therefore, for the integration of theory and practice, first of all, the practice teaching base should fully realize the importance of theoretical knowledge, and theoretical knowledge is the basis of professional activities, and theoretical knowledge must be explicitly included in 
to the professional activities. Secondly, the practice teaching base should provide favorable conditions for the students to accumulate practical experience.

The matching degree of curriculum and work refers to the matching degree of the course content and job demands. In the city management professional education, the curriculum must establish close contact with the professional. The course should match the professional, should have a certain degree of adaptability, otherwise the training of talents will not be able to meet the needs of the city and the applied talents of social management.

The matching degree of the curriculum and professional can be mastered from two aspects. First, the city management should take employment as the guidance, and the curriculum has distinct occupational characteristics, and curriculum content should aim at the demand of market and industry to strengthen the matching degree of curriculum and professional as far as possible. Secondly, under the concept of competence-based education, city management professional curriculum reform should determine vocational ability system based on the analysis of the professional .Every profession has its own professional standards and professional ability request. After dealing with problems of the professional positioning and market consistent with professional, determine problem of the professional ability need to be considered. In the concept of competence-based education, it contains the professional features. This requires the development of the city management professional course system and design should accord to requirements for professional standards and ability, taking professional standards and capacity requirements as the curriculum goal, set specific course content, so that the training of talents can meet the professional requirements.

\subsection{Teaching methods and practice base construction}

The teaching way is one of the important factors to influence city management professional students' vocational ability education effect. According to the developing rules and attributes of professional ability, in order to achieve the core of city management professional ability training goal, the practice base needs to reform the traditional teaching method to the existing methods.

In the process of city management professional teaching, classroom teaching is still the most basic and indispensable teaching methods for students. At the same time of focusing on classroom teaching, practice teaching also should be paid attention. Years of training practice shows that the practice teaching is a very effective teaching method of city management. This kind of teaching method has played a very big role of cultivating the students' vocational ability, and its experience and effectiveness is very strong, and the forms of general teaching practice such as visits, case analysis, and simulation scene are hard to reach the same effect.

Strengthening the practice teaching, in value of practice and training is the core of urban management professional education, is the way to realize the city management professional training objectives and training senior applied talents. Universities should build a systematic practice teaching system that consists of laboratory, campus practice base and off-campus practice base; at the same time, they must strengthen the practice teaching environment construction and improve the practice conditions, strengthen the practice teaching, expand practice teaching depth. Through various channels, college students can improve operation ability and application ability. In addition, universities can provide a favorable external environment for the teachers and students in scientific research that not only can promote the theory teaching, can also be used to lay a foundation to improve the students' further work.

\section{CONSTRUCTION OF CITY MANAGEMENT PROFESSIONAL PRACTICE TEACHING BASE}

\subsection{Mutual benefit and win-win cooperation}

City management professional undergraduate course practice teaching base construction is mainly in the form of cooperation, and the goal is to achieve mutual benefit, and it is also the main ideas in the practice teaching base construction. This would require the cooperation of both sides to take the ideas of mutual benefit as the basis, effectively maintain long-term stable development and sustained cooperation, through external resources to resolve the problems of the hardware facilities construction, through the internal conditions to improve management and innovation of practice teaching base products, and through the practice teaching base cooperation to broaden areas of cooperation between the two sides, to achieve the diversification of solid cooperation.

\subsection{The value of people-oriented}

Practice teaching base in essence belongs to the education teaching activity. This kind of teaching activity is composed of teachers and students; it is the cooperation product of universities, enterprises and government. City management professional practice teaching base construction should accord to the nature of the practice teaching, adhere to the people-centered thought, and the direct purpose of cultivation is to improve the students' knowledge and skills. Therefore, the value of people-oriented 
should be embodied from the goal setting of practice teaching to the development of the teaching activities, from the innovation of teaching methods to settings of practice teaching content. From this perspective, the practice teaching base construction should embody all in order to meet the value orientation of teacher and student interests, to coordinate the relationship between the organizational units and teachers, students, to coordinate the relationship between the teachers and students, and to achieve the optimal effect of practice teaching. City management is for urban service industry, based on the characteristics of the industry, first in terms of talent training it should reflect the students' subject status, so that can continue this kind of idea in future work, and improve the overall service quality and level of city development.

\subsection{Open education and diversified mechanism}

The open education is the fundamental idea of solving the problem of city management professional development and breaking through the practice teaching base construction. The thought of "going out" must be carried out for the construction of universities teaching practice base, and through continuous developing development space of practice teaching base, and establishing diversified cooperation pattern with the social organization and the government. For city management professional practice teaching base construction, it is the necessary for the professional development of city management to cooperate with social organizations, governments at all levels and other units, and make the teaching contents and teaching methods into practice, to absorb widely the social resources, and to realize the social development of the practice teaching base.

\subsection{Resource sharing and social education}

Resource sharing is the important thought of city management professional practice teaching base construction. Unlike the idea of mutual benefit, sharing ideas is refers to achieving a state of relative harmony in the content and form of cooperation, fully putting into its advantage resources projects, improving the service scope of the practice teaching base, and achieving win-win effect. City management professional practice teaching base is to improve professional skills of city management talents, and is the cooperation organization of providing high level specialized talents for the industry of city service. Based on the mutual benefit of the government and colleges and universities, the practice teaching base should contribute to the results of this practice to play its greater contribution, such as introducing the successful experience of practice base construction to other professional practice base construction, and can absorb a variety of educational resources, such as making use of social resources, forming a diversified cooperation mechanism, eventually sharing resource of practice achievements, promoting the practice teaching base of the relevant factors, including the subjects of cooperation, activities, etc to make benefit from it. This is the ideological and value pursuit of the practice teaching base construction.

\subsection{Consistent with the major teaching organization}

Urban management professional practice teaching base is mainly to complete the basic professional ability training and professional practice ability training. The cultivation of professional ability training and standard the cultivation is the basis of city management professional practice teaching base construction. The hardware of the base is making service for software, is in the service of the ability training project and standard. The software and hardware facilities of the practice base should began to make application in relevant industry or industry, and can represent the industry development trend that in a short period of time can reflect the advancement in this field. This must be properly grasping the relationship between necessary and satisfied, and to seek appropriate cost performance. It is the most fundamental for satisfying the real need

\subsection{Grasping complementary relationship of on- campus and off-campus practice base construction}

The construction structure and layout of city management practice teaching base need to apply to professional organization of practice teaching and students' learning characteristics, and combine with professional ability promotion rules of cultivating students. Some basic ability training cannot or are not suitable for carrying out outside school, and it needs to be done on campus practice teaching base, and off-campus practice base is mainly to complete the training of the professional environment, the professional norms, ethics, etc. Therefore, it must be properly grasp complementary relationship of the internal and external practice teaching base construction, to effectively complete city management major students' practice teaching tasks.

\section{CONCLUSION}

Strengthening the construction of teaching practice base is an important task for the construction of colleges and universities teaching, is one of the important measures to ensure the practice teaching, 
improve teaching quality, and establish professional characteristics. Practice base construction is the essential foundational condition of the urban management professional teaching, is the carrier of students for professional practice. City management is the major that has the strong application. As an important part of teaching, practice teaching occupies important position in the cultivation of students' quality and ability, it is irreplaceable for other teaching process. Focusing on practice base construction is the important guarantee of improving teaching quality of city management comprehensively. Strengthening the construction of practice base platform can improve teachers' understanding of the practice teaching, and help to further improve the quality of practice teaching. Good practice base construction can strongly promote the reform of practice of teaching content, teaching system, the teaching methods and teaching means.

\section{REFERENCES}

[1] X.N.Dong.2006.On the Construction of University Student Social Practice Base. Central China Normal University Master's thesis.

[2] W.J.Shao.2014.Study on the Tourism Management Undergraduate Practical Teaching Base Construction. Shenyang Normal University Master's thesis.

[3] X.T.Wu.2009.Research and Exploration in Public Training Base. East China Normal University Doctoral thesis.

[4] J.H.Xiang.2007.Research on Colleges Practice Base Construction. Central South University Central South University. 